\title{
Profielschets uitkeringsafhankelijke inwoners in Limburg
}

Citation for published version (APA):

Künn, A., Poulissen, D., \& de Grip, A. (2020). Profielschets uitkeringsafhankelijke inwoners in Limburg. ROA. ROA Fact Sheets No. 005 https://doi.org/10.26481/umarof.2020005

Document status and date:

Published: 21/06/2020

DOI:

10.26481/umarof.2020005

Document Version:

Publisher's PDF, also known as Version of record

\section{Please check the document version of this publication:}

- A submitted manuscript is the version of the article upon submission and before peer-review. There can be important differences between the submitted version and the official published version of record.

People interested in the research are advised to contact the author for the final version of the publication, or visit the DOI to the publisher's website.

- The final author version and the galley proof are versions of the publication after peer review.

- The final published version features the final layout of the paper including the volume, issue and page numbers.

Link to publication

\footnotetext{
General rights rights.

- You may freely distribute the URL identifying the publication in the public portal. please follow below link for the End User Agreement:

www.umlib.nl/taverne-license

Take down policy

If you believe that this document breaches copyright please contact us at:

repository@maastrichtuniversity.nl

providing details and we will investigate your claim.
}

Copyright and moral rights for the publications made accessible in the public portal are retained by the authors and/or other copyright owners and it is a condition of accessing publications that users recognise and abide by the legal requirements associated with these

- Users may download and print one copy of any publication from the public portal for the purpose of private study or research.

- You may not further distribute the material or use it for any profit-making activity or commercial gain

If the publication is distributed under the terms of Article $25 \mathrm{fa}$ of the Dutch Copyright Act, indicated by the "Taverne" license above, 


\section{Maastricht University $\&$ ROA}

\section{Profielschets uitkeringsafhankelijke inwoners in Limburg}

Annemarie Künn-Nelen

Davey Poulissen

Andries de Grip

\section{ROA Factsheet}

ROA-F-2020/5

Researchcentrum voor Onderwijs en Arbeidsmarkt | ROA Research Centre For Education and the Labour Market / ROA 


\section{Profielschets uitkeringsafhankelijke inwoners in Limburg}

Snelle feiten en cijfers

- Het profiel van inactieven zonder uitkering is over de gehele linie (gezondheid, financiële situatie, opleidingsniveau, migratiestatus en gezinssamenstelling) veel sterker dan dat van uitkeringsafhankelijken.

- Bij alle groepen uitkeringsafhankelijken (arbeidsongeschiktheid, werkloosheid en bijstand) is de financiële problematiek het grootst in de Zuid-Limburgse gemeenten.

- Gezondheidsproblemen komen veel vaker voor onder mensen in de bijstand dan onder mensen met een werkloosheidsuitkering. Gemeenten in MiddenLimburg hebben een hoger aandeel bijstandsontvangers met gezondheidsproblemen dan de gemeenten in Noord- en Zuid-Limburg.

- In de Limburgse gemeenten heeft tussen de $62 \%$ en $79 \%$ van alle bijstandontvangers financiële problemen. Dat is veel hoger dan bij de mensen met een werkloosheidsuitkering, waarvan in de Limburgse gemeenten tussen de $14 \%$ en $29 \%$ financiële problemen heeft.

- Het percentage mensen in de bijstand dat een vmbo diploma of lager heeft, loopt tussen de Limburgse gemeenten uiteen van $36 \%$ tot $64 \%$.

- In Limburgse gemeenten is het percentage mensen dat deel uitmaakt van een éénoudergezin het hoogst onder bijstandsontvangers (tussen de $6 \%$ en $17 \%)$. Onder andere in de Oostelijke Mijnstreek is dit percentage hoog.

- Bij 18 van de in totaal 31 Limburgse gemeenten is er sprake van meervoudige problematiek onder de bijstandsontvangers. Bij vier gemeenten is er zelfs vaak sprake een zeer complexe problematiek (hoge score op minimaal vier van de vijf profielkenmerken).

\section{Inleiding}

In december 2017 had Limburg een potentiële beroepsbevolking van ruim 740.000 mensen. ${ }^{1}$ In een eerdere factsheet hebben we voor elke gemeente in Limburg de omvang van vier groepen mensen met een kwetsbare arbeidsmarktpositie in kaart gebracht. ${ }^{2}$ Daarbij werden drie groepen uitkeringsafhankelijken onderscheiden: (1) personen met een arbeidsongeschiktheidsuitkering (AO-uitkering), (2) personen met een werkloosheidsuitkering (WW-uitkering) en (3) personen met een bijstandsuitkering. Daarnaast werden ook degenen die inactief waren zonder dat ze één (of meerdere) van de hierboven genoemde uitkeringen te ontvingen bestempeld als kwetsbaar. ${ }^{3}$

Deze factsheet richt zich op de vraag hoe kansarm of kansrijk mensen in een kwetsbare positie zijn. We brengen dit in kaart door een profielschets te maken van de drie groepen uitkeringsontvangers. ${ }^{4}$ Deze profielschets is gebaseerd op vijf aspecten:

- Gezondheidsproblematiek

- Financiële problematiek

- Opleidingsniveau

- Migratieachtergrond

- Gezinssituatie

We definiëren een gezondheidsprobleem als het ervaren van een chronische ziekte of aandoening. Daarbij kijken we naar de mate waarin iemand arbeidsongeschikt is verklaard door het UWV en het medicijngebruik. ${ }^{5}$ Financiële problematiek wordt in kaart gebracht op basis van deelname aan schuldsanering, het hebben van een huishoudinkomen onder de armoedegrens of het hebben van schulden boven de 10.000 Euro. lemand met een laag opleidingsniveau heeft ten hoogste een vmbo diploma. ${ }^{6}$ Wat betreft migratieachtergrond maken wij een onderscheid tussen het al dan niet hebben van een niet-Westerse migratieachtergrond.? Het vijfde aspect dat deel uitmaakt van de profielschets betreft het deel uitmaken van een éénoudergezin.

In deze factsheet laten we voor elke Limburgse gemeente zien wat het percentage mensen is met een bepaalde uitkering, waarvoor deze vijf aspecten van toepassing zijn. Hiermee verschaffen we inzicht in het achterliggende profiel van uitkeringsafhankelijken. Ook laten we zien in hoeverre er in Limburgse gemeenten sprake is van een opeenstapeling van deze aspecten. We beperken ons hier tot de verschillen tussen de gemeenten. In een apart rapport voor de gemeente Heerlen laten we zien dat de profielschetsen ook op wijkniveau gemaakt kunnen worden. ${ }^{8}$

Omdat deze vijf aspecten vaak gerelateerd zijn aan een kleinere kans om werkzaam te zijn en/of op de arbeidsmarkt te reintegreren, ${ }^{9}$ spreken we bij de stapeling van deze aspecten over de complexiteit van de problema- 


\section{Factsheet}

ROA-F-2020/5

TABEL 01.

Profielschets inwoners Provincie Limburg*

\begin{tabular}{|c|c|c|c|c|c|c|}
\hline & & $\begin{array}{l}\text { Gezondheids- } \\
\text { problematiek }\end{array}$ & $\begin{array}{r}\text { Financiële } \\
\text { problematiek }\end{array}$ & $\begin{array}{r}\text { Laag opleidings- } \\
\text { niveau** }^{* *}\end{array}$ & $\begin{array}{l}\text { Niet-Westerse } \\
\text { migratie-achtergrond }\end{array}$ & Één-oudergezin \\
\hline \multirow{4}{*}{ 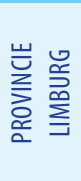 } & Alle inwoners & $43 \%$ & $24 \%$ & $21 \%$ & $5 \%$ & $3 \%$ \\
\hline & Werkenden & $38 \%$ & $20 \%$ & $14 \%$ & $3 \%$ & $3 \%$ \\
\hline & Uitkeringsafhankelijken & $65 \%$ & $38 \%$ & $43 \%$ & $10 \%$ & $6 \%$ \\
\hline & Inactieven & $44 \%$ & $26 \%$ & $33 \%$ & $11 \%$ & $2 \%$ \\
\hline \multirow{4}{*}{ 总 } & Alle inwoners & $39 \%$ & $26 \%$ & $18 \%$ & $9 \%$ & $3 \%$ \\
\hline & Werkenden & $34 \%$ & $23 \%$ & $11 \%$ & $6 \%$ & $3 \%$ \\
\hline & Uitkeringsafhankelijken & $61 \%$ & $41 \%$ & $40 \%$ & $20 \%$ & $8 \%$ \\
\hline & Inactieven & $42 \%$ & $29 \%$ & $30 \%$ & $16 \%$ & $2 \%$ \\
\hline
\end{tabular}

Bron: $R O A$, berekeningen op basis van microdata van het $C B S$

* Het betreft hier alleen inwoners die vallen onder de potentiële beroepsbevolking en die niet schoolgaand zijn en geen (vervroegd) pensioen ontvangen. De groep werkenden heeft betrekking op de mensen die daarnaast geen (AO, WW of bijstands)uitkering ontvangen.

** Informatie over het opleidingsniveau is alleen gebaseerd op mensen geboren vóór 1994.

tiek. We onderscheiden hierbij vier gradaties: geringe problematiek, enkelvoudige problematiek, meervoudige problematiek en complexe problematiek..$^{10}$

Maar eerst toont deze factsheet de profielschets van de Provincie Limburg in haar totaliteit. Hierbij onderscheiden we werkenden, uitkeringsafhankelijken en inactieven, waarbij we nog geen onderscheid maken naar gemeenten.

\section{Profielschets van de Provincie Limburg}

Tabel 1 laat zien in hoeverre inwoners te maken hebben met chronische gezondheidsproblemen, financiële problemen, een laag opleidingsniveau, een nietWesterse migratieachtergrond en het leven in een éénoudergezin. We maken hierbij onderscheid tussen werkenden, uitkeringsafhankelijken en inactieven, en vergelijken de situatie in de Provincie Limburg met het gemiddelde in Nederland.

Gemiddeld heeft 43\% van alle inwoners in Limburg chronische gezondheidsproblemen, maar het verschil tussen de drie onderscheiden groepen is groot. Terwijl $38 \%$ van de werkenden een chronisch gezondheidsprobleem ervaart, is dit percentage onder uitkeringsafhankelijken met $65 \%$ veel groter. Van de inactieven heeft $44 \%$ te maken met chronische gezondheidsproblemen.
Deze percentages zijn iets hoger dan gemiddeld voor Nederland. ${ }^{11}$

Financiële problemen blijken in Limburg onder alle onderscheiden groepen juist iets minder vaak voor te komen. Terwijl gemiddeld $24 \%$ van alle mensen woonachtig in Limburg grote financiële problemen ervaart, geldt ook hier weer dat dit percentage veel hoger uitvalt onder uitkeringsafhankelijken (38\%) dan onder werkenden (20\%). Onder de inactieven hebben veel minder mensen financiële problemen (26\%) dan onder de uitkeringsafhankelijken.

In Limburg is ongeveer 1 op de 5 inwoners laagopgeleid. Hiermee is het aandeel laag opgeleiden in Limburg iets hoger dan gemiddeld voor Nederland. Er zijn ook hier grote verschillen tussen de drie onderscheiden groepen. Van de uitkeringsafhankelijken in Limburg is $42 \%$ laag opgeleid. Dat is ongeveer drie keer zo hoog dan onder de werkenden in Limburg (14\%).

Een niet-westerse migratieachtergrond komt in Limburg minder vaak voor dan gemiddeld in Nederland. Slechts $5 \%$ van de inwoners heeft deze migratieachtergrond. Onder uitkeringsafhankelijken en inactieven is dit percentage ongeveer $10 \%$; onder de werkenden slechts $3 \%$. Ook gemiddeld in Nederland is het percentage mensen met een niet-Westerse migrantieachtergrond veel hoger onder uitkeringsafhankelijken en inactieven dan onder de werkenden. 


\section{Profielschets uitkeringsafhankelijke inwoners in Limburg}

De mate waarin mensen in Limburg deel uitmaken van een éénoudergezin wijkt niet af van het Nederlandse gemiddelde: $3 \%$ van alle inwoners in Limburg is alleenstaand met kinderen. Onder uitkeringsafhankelijken is dit met $6 \%$ in Limburg en $8 \%$ in Nederland beduidend hoger.

Het profiel van inactieven zonder uitkering is over de gehele linie veel sterker dan dat van uitkeringsafhankelijken. Gezondheids- en financiële problemen komen onder inactieven beduidend minder vaak voor dan onder uitkeringsafhankelijken. Ook is er tussen inactieven en uitkeringsafhankelijken een aanzienlijk verschil in het percentage mensen met een laag opgeleidingsniveau. We zullen daarom in de rest van deze factsheet, waarin we ingaan op de verschillen tussen gemeenten, alleen profielschetsen maken van de uitkeringsafhankelijken.

\section{Profielschets van mensen met een AO- uitkering in Limburgse gemeenten}

In de Figuren 1-5 wordt per gemeente het percentage mensen met een AO-uitkering dat te maken heeft met de vijf aspecten die hen kansarmer maken in kaart gebracht. ${ }^{2}$ De verschillende blauwtonen geven de relatieve positie van de gemeenten weer ten opzichte van alle gemeenten in Limburg. Hoe donkerder de arcering, hoe groter de relatieve problemen voor de desbetreffende groep inwoners. ${ }^{13}$

\section{Gezondheidsproblematiek}

Figuur 1 gaat in op de mate waarop in de Limburgse gemeenten sprake is van gezondheidsproblemen onder arbeidsongeschikten. Zoals verwacht mocht worden is bij deze groep in alle Limburgse gemeenten het percentage mensen dat kampt met gezondheidsverschillen hoog, waarbij er relatief weinig verschillen zijn.
In Vaals is het percentage AO-ontvangers dat chronische problemen ervaart met $69 \%$ het laagst, in Landgraaf, Nederweert, Peel en Maas en Weert is het percentage met $76 \%$ daarentegen het hoogst. Vier van de zeven gemeenten met een zeer hoge problematiek liggen in Midden-Limburg.

\section{Financiële problematiek}

Figuur 2 laat zien in hoeverre in de Limburgse gemeenten mensen met een AO-uitkering financiële problemen hebben. In een zestal gemeenten komen financiële problemen bij minder dan $21 \%$ van de arbeidsongeschikten voor: Leudal, Horst aan de Maas, Maasgouw, Beesel en Roerdalen en Nederweert. In Heerlen en Vaals daarentegen hebben iets meer dan 30\% van de arbeidsongeschikten financiële problemen. Naast deze twee gemeenten, zijn er nog drie Zuid-Limburgse gemeenten waar relatief zeer veel AO-ontvangers financiële problemen hebben: SittardGeleen, Kerkrade en Maastricht. Hetzelfde geldt ook voor Roermond (Midden-Limburg) en Venlo (NoordLimburg).

\section{Laag opleidingsniveau}

Figuur 3 laat zien in welke mate mensen met een AO-uitkering in Limburg laagopgeleid zijn. In Mook en Middelaar is minder dan $25 \%$ van de AO-ontvangers laag opgeleid. Hiermee behoort deze gemeente zelfs bij de 10 gemeenten in Nederland met de minste laagopgeleiden onder de arbeidsongeschikten. Bij de andere gemeenten met zeer weinig laaggeschoolden onder de AO-ontvangers varieërt dit percentage tussen de $29 \%$ en $38 \%$. In de gemeenten met een zeer hoge relatieve positie is $46 \%$ tot $54 \%$ van de AO-ontvangers laag opgeleid. Het betreft hier een viertal Zuid-Limburgse gemeenten: Maastricht, Kerkrade, Landgraaf, Brunssum en drie Noord-Limburgse gemeenten: Venray, Beesel en Venlo. 


\section{Factsheet}

ROA-F-2020/5

FIGUUR 01.

Relatieve positie van gemeenten op het gebied van gezondheidsproblematiek onder mensen met een AO-uitkering

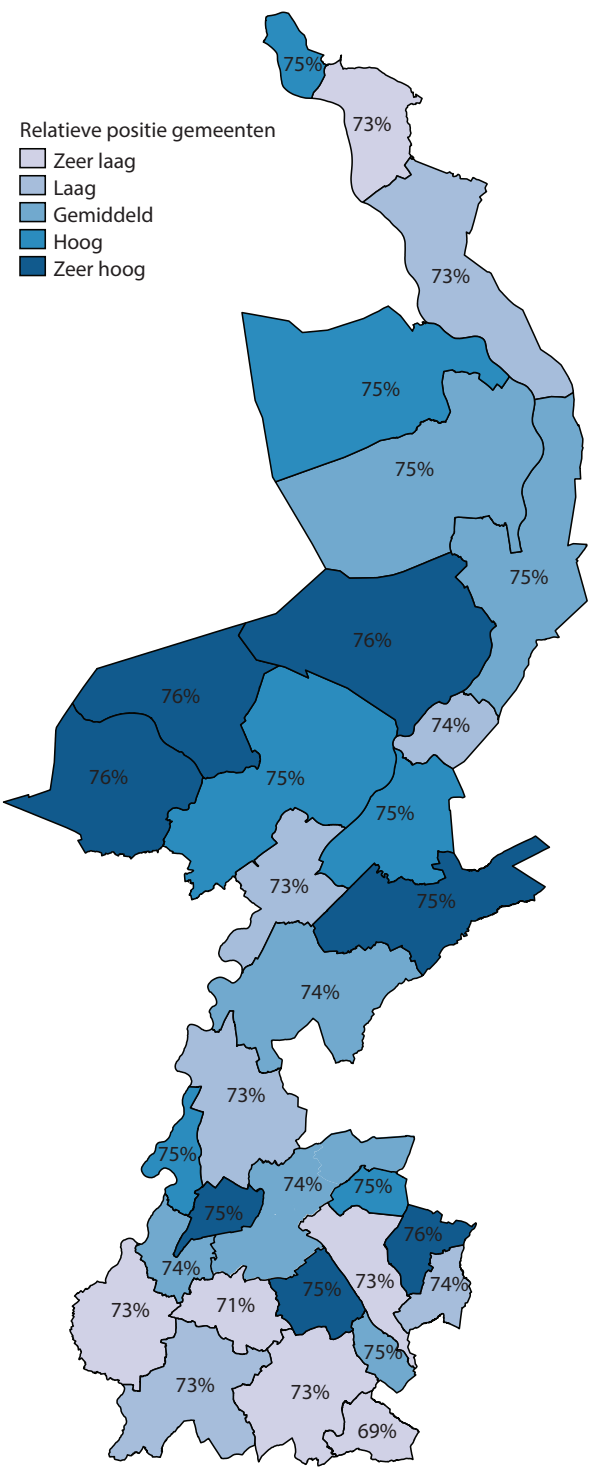

Bron: $R O A$, berekeningen op basis van microdata van het $C B S$
FIGUUR 02.

Relatieve positie van gemeenten op het gebied van financiële problematiek onder mensen met een AO-uitkering

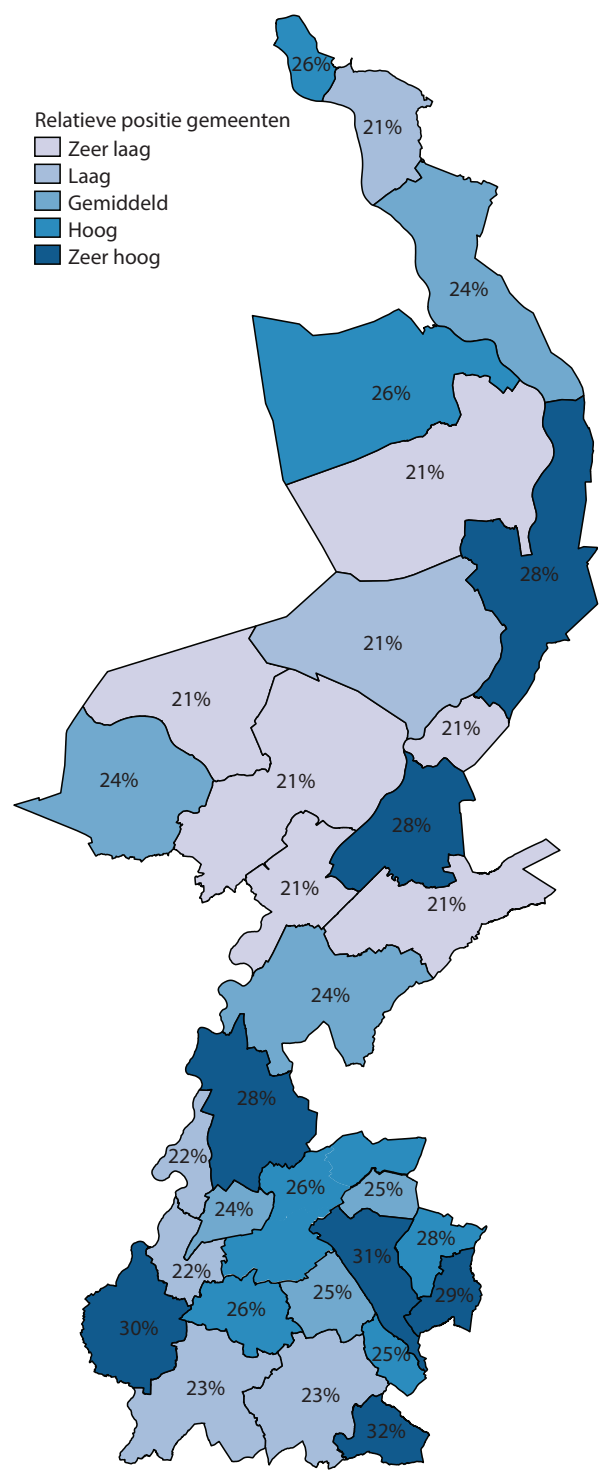

Bron: $R O A$, berekeningen op basis van microdata van het $C B S$
FIGUUR 03.

Relatieve positie van gemeenten op het gebied van laag opleidingsniveau onder mensen met een AO-uitkering

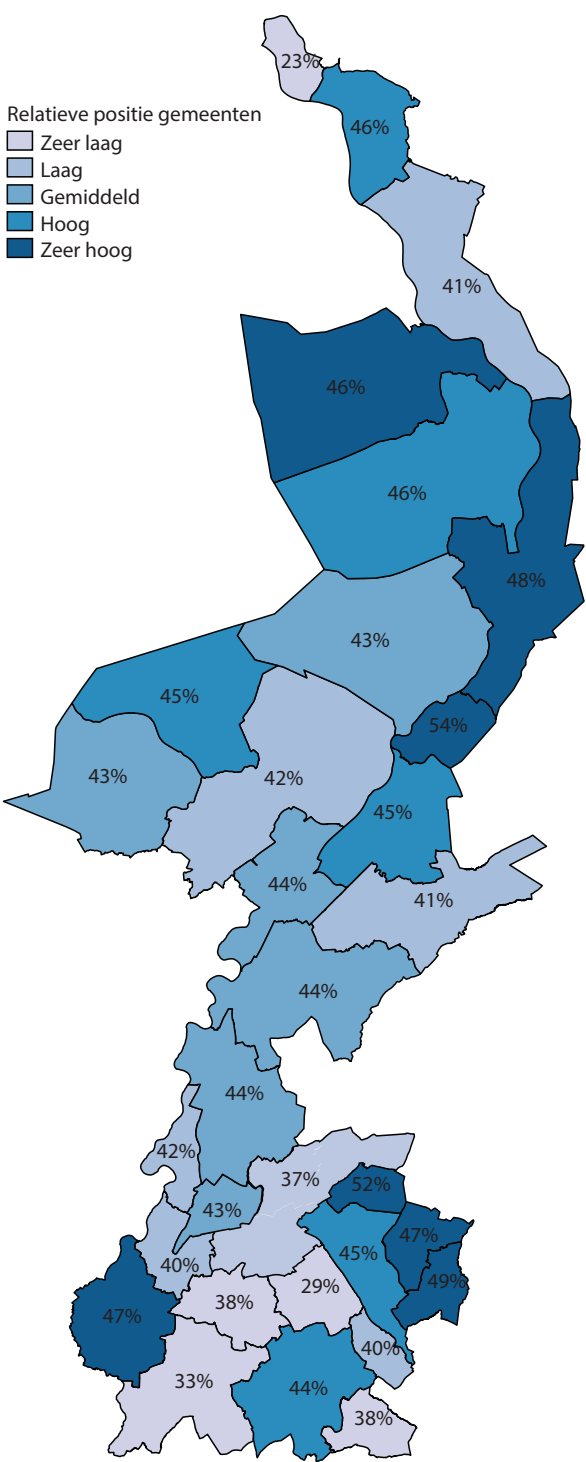

Bron: $R O A$, berekeningen op basis van microdata van het $C B S$ 


\section{Profielschets uitkeringsafhankelijke inwoners in Limburg}

Niet-westerse migratieachtergrond

Uit Figuur 4 blijkt dat een niet-westerse migratieachtergrond onder AO-ontvangers in Limburg het meeste voorkomt in de grotere steden: Heerlen, Maastricht, Sittard-Geleen, Weert, Venlo en Roermond. Ook Venray heeft een relatief hoog aandeel niet-westerse migraten onder de AO-ontvangers. Opvallend is wel dat in de drie Zuid-Limburgse steden (Heerlen, Maastricht en SittardGeleen) het percentage arbeidsongeschikten met een niet-westerse migratieachtergrond rond de $5 \%$ ligt, terwijl voor de andere steden dit percentage tussen de $10 \%$ en $13 \%$ ligt. In Simplveld is het percentage arbeidsongeschikten met een niet-westerse migratieachtergrond het laagste: 0,4\%. Een percentage dat ook laag is vergeleken met andere Nederlandse gemeenten. ${ }^{14}$

\section{Éénoudergezin}

In Figuur 5 is het percentage en de relatieve positie van gemeenten met betrekking tot het voorkomen van éénoudergezinnen onder AO-ontvangers weergegeven. Uit de figuur blijkt dat éénoudergezinnen onder AO-ontvangers het meest voorkomen in de ZuidLimburgse gemeenten. Naast de steden Maastricht en Heerlen, behoren ook Meerssen, Landgraaf, Voerendaal, Brunssum en Simpelveld, met percentages rond de 5 , tot de gemeenten met relatief zeer veel éénoudergezinnen onder de arbeidsongeschikten.

Complexiteit van de problematiek

Vervolgens is bekeken in hoeverre AO-ontvangers in de Limburgse gemeenten vaak te maken hebben met meerdere reïntegratie belemmerende factoren. Daarbij maken we gebruik van een complexiteitsindex van de problematiek op gemeenteniveau. Deze index is een optelsom van het aantal reïntegratie belemmerende factoren waarmee een gemeente (zeer) vaak te maken heeft. Op basis van de index kan een kwalitatieve typering van de ernst van de problematiek worden gegeven: geringe problematiek (geen factoren die relatief (zeer) vaak voorkomen), enkelvoudige problematiek (één factor die relatief (zeer) vaak voorkomen), meervoudige problematiek (twee of drie factoren die relatief (zeer) vaak voorkomen) en een zeer complexe problematiek (vier of vijf factoren die relatief (zeer) vaak voorkomen. In Figuur 6 wordt deze typering in kaart gebracht.

Uit de figuur blijkt dat vijf gemeenten gekenmerkt worden door een zeer complexe problematiek..$^{15} \mathrm{Het}$ gaat om de gemeenten Landgraaf, Heerlen, Maastricht, Roermond en Venray. 16 van de in totaal 31 Limburgse gemeenten worden gekenmerkt door een meervoudige problematiek. In een zestal gemeenten is de problematiek enkelvoudig, wat betekent dat de gemeente, onder arbeidsongeschikten, slechts op één aspect een (zeer) hoge relatieve positie inneemt: Meerssen (éénoudergezin), Valkenburg aan de Geul en Beekdaelen (financiële problematiek), Horst aan de Maas en GulpenWittem (laag opleidingsniveau) en Leudal (gezondheidsproblematiek). In Bergen, Maasgouw, Echt-Susteren en Eijsden-Margraten hebben veel arbeidsongeschikten in vergelijking met de andere Limburgse gemeenten een sterk profiel. 


\section{Factsheet}

ROA-F-2020/5

\section{FIGUUR 04.}

Relatieve positie van gemeenten op het gebied van niet-westerse migratieachtergrond onder mensen met een AO-uitkering

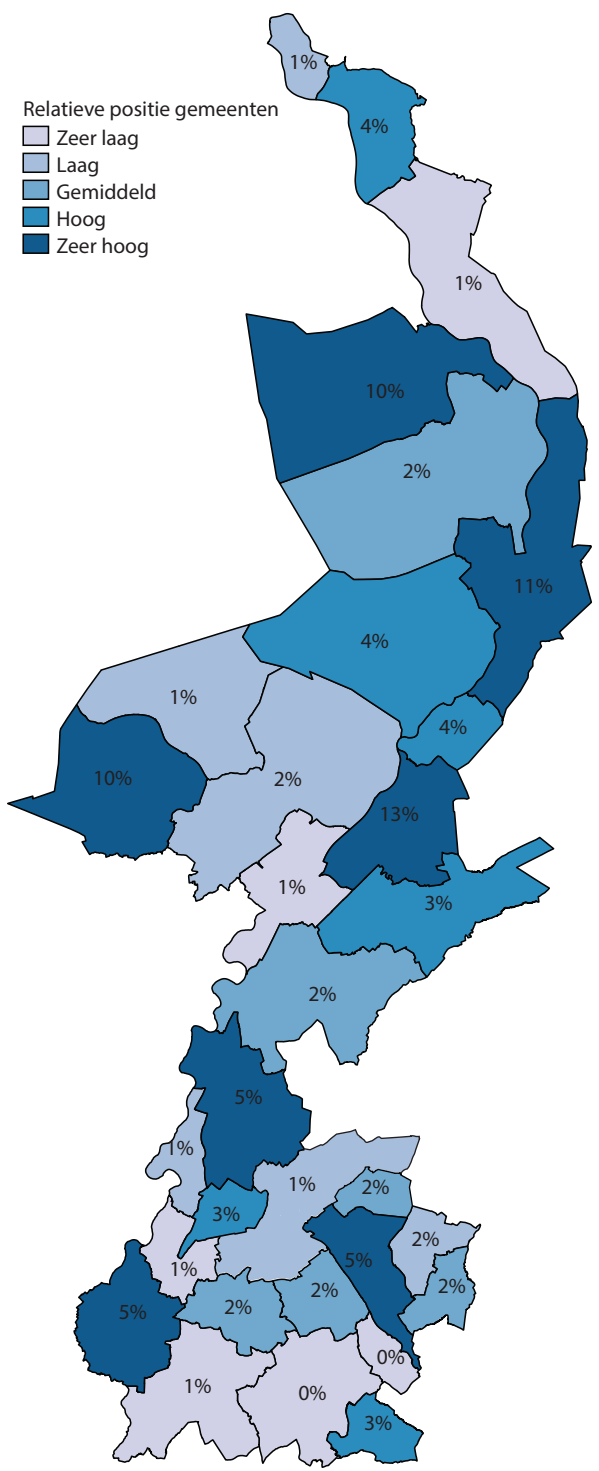

Bron: $R O A$, berekeningen op basis

van microdata van het $C B S$
FIGUUR 05.

Relatieve positie van gemeenten op het gebied van éénoudergezin onder mensen met een AO-uitkering

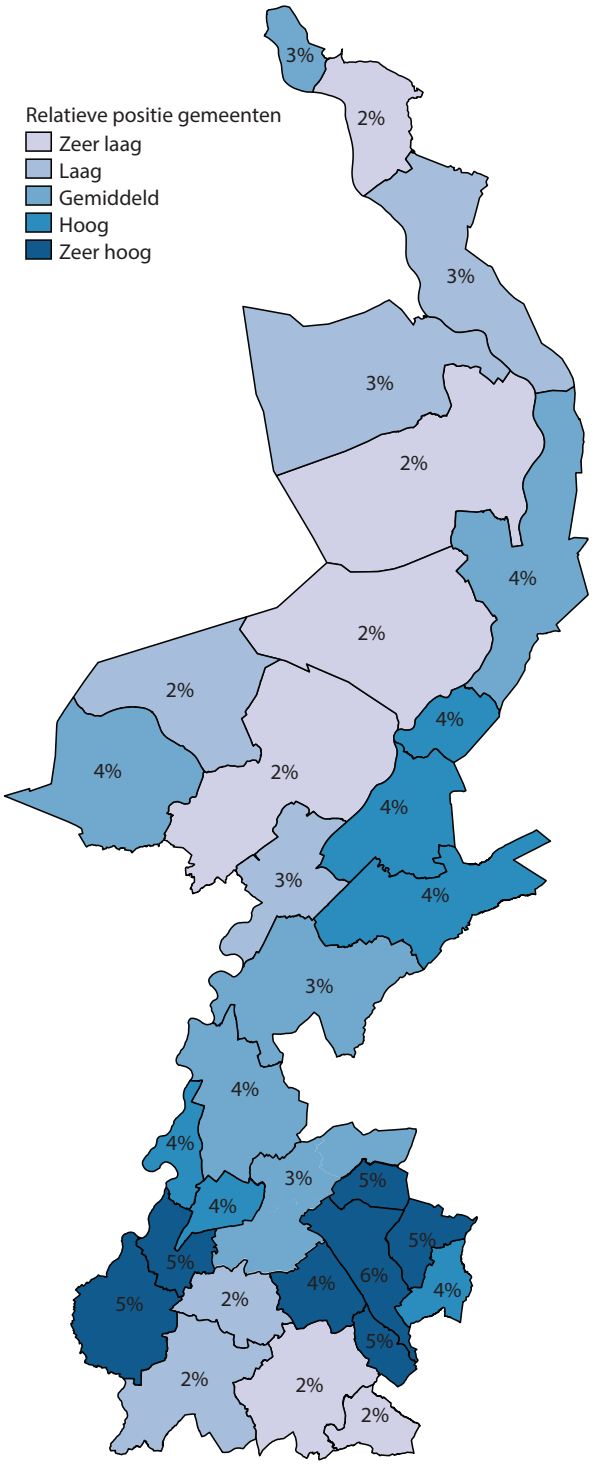

Bron: ROA, berekeningen op basis van microdata van het $C B S$
FIGUUR 06.

Complexiteitsindex van gemeenten op gericht op mensen met een AO-uitkering

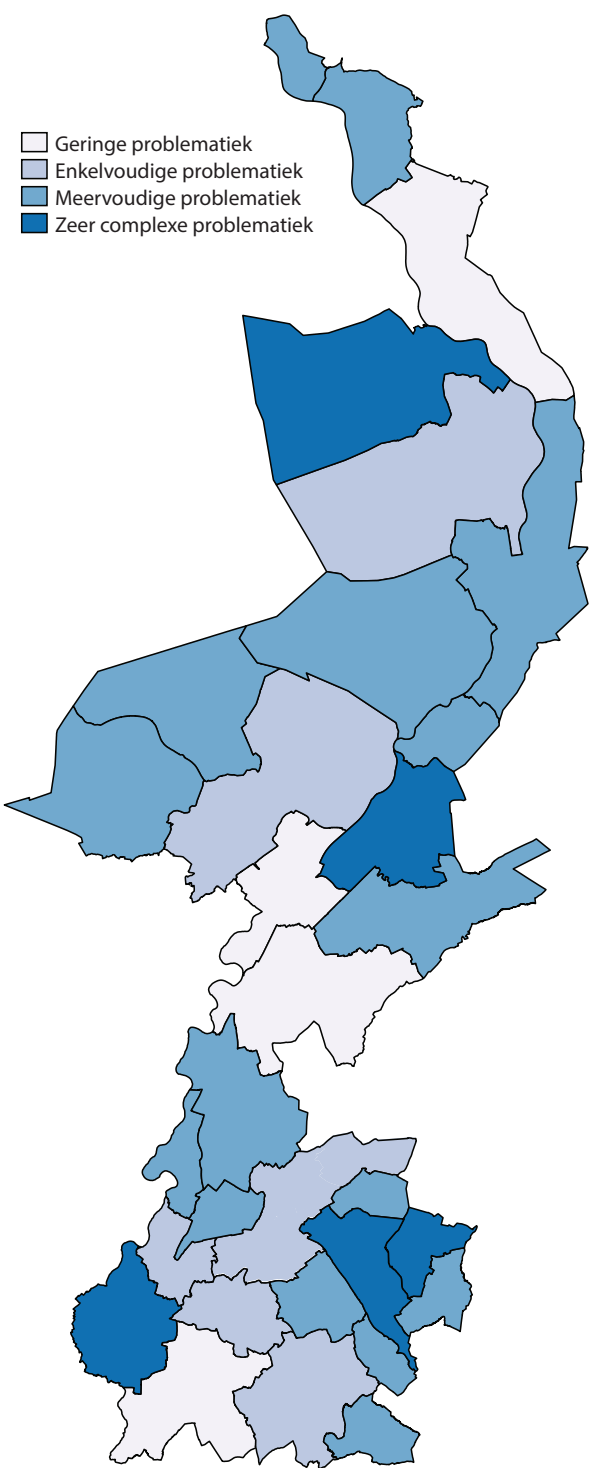

Bron: $R O A$, berekeningen op basis van microdata van het $C B S$ 


\section{Profielschets uitkeringsafhankelijke inwoners in Limburg}

\section{Profielschets van mensen met een WW- uitkering in Limburgse gemeenten}

In de Figuren 7-12 is op gemeenteniveau het profiel voor mensen met een werkloosheidsuitkering in kaart gebracht. ${ }^{16}$

\section{Gezondheidsproblematiek}

Figuur 7 gaat in op de mate waarin er in de Limburgse gemeenten sprake is van gezondheidsproblemen onder mensen met een WW-uitkering. Gezondheidsproblemen komen, zoals verwacht mag worden, duidelijk minder vaak voor onder mensen met een WW- dan bij mensen met een AO-uitkering. In de gemeenten Beekdaelen, Venlo, Leudal, Roerdalen, Weert, Kerkrade en Bergen komen gezondheidsproblemen onder hun inwoners met een WW-uitkering het meest voor. Van alle WW-ontvangers in deze gemeenten heeft tussen de $49 \%$ en $54 \%$ chronische gezondheidsklachten. Bergen, waar $54 \%$ van de WW-ontvangers gezondheidsproblemen heeft, behoort bovendien bij de 10 gemeenten in Nederland met de meeste gezondheidsproblemen onder de mensen met een WW-uitkering. In de gemeenten Vaals, Beesel, Mook en Middelaar, Gennep, Eijsden-Margraten en Beek, komen gezondheidsproblemen onder WW-ontvangers juist relatief weinig voor (tussen de $41 \%$ en $45 \%$ ).

\section{Financiële problematiek}

In Figuur 8, is weergegeven in hoeverre mensen met een WW-uitkering te kampen hebben met financiële problemen. Voor alle gemeenten geldt dat minder dan één op de drie WW-ontvangers financiële problemen ervaart. In Voerendaal, Beekdaelen, Roermond, Vaals, Sittard-Geleen, Maastricht en Valkenburg aan de Geul hebben mensen met een WW-uitkering relatief gezien zeer vaak te maken met financiële problemen (tussen $24 \%$ en 29\%). Het is opmerkelijk dat vijf van deze gemeenten in Zuid-Limburg liggen. Ook de zeven gemeenten met relatief veel WW-ontvangers met financiële problemen liggen in Zuid-Limburg. Financiële problemen onder WW-ontvangers zijn dus geconcentreerd in de Zuid-Limburgse gemeenten. In Noord en Midden-Limburg komen financiële problemen onder WW-ontvangers duidelijk minder voor. Tot de zes gemeenten met relatief weinig WW-ontvangers met financiële problemen ligt slechts één gemeente in ZuidLimburg: Stein. Net als in Stein, hebben ook in Horst aan de Maas, Bergen, Leudal, Maasgouw en Venray, minder dan $17 \%$ van de WW-ontvangers financiële problemen. Bergen en Horst aan de Maas behoren bovendien bij de 10 gemeenten in Nederland met de minste financiële problemen onder de WW-ontvangers in hun gemeente.

\section{Laag opleidingsniveau}

Figuur 9 laat zien in welke mate mensen geboren vóór 1994 met een WW-uitkering in Limburg een laag opleidingsniveau hebben. Voor alle gemeenten geldt dan minder dan één op de vier WW-ontvangers laagopgeleid is. Terwijl de AO-ontvangers in Mook en Middelaar het hoogst opgeleid zijn ten opzichte van andere Limburgse gemeenten, hebben de WW-ontvangers in deze gemeenten juist relatief vaak maximaal een vmbo diploma. ${ }^{17}$ Andere gemeenten met verhoudingsgewijs zeer veel WW'ers met een laag opleidingsniveau zijn Venlo, Brunssum, Bergen, Beesel, Kerkrade en Heerlen. De gemeenten Stein, Meerssen, Vaals, Voerendaal, Eijsden-Margraten - allemaal Zuid-Limburgse gemeenten - behoren tot de Limburgse gemeenten met een relatief zeer laag percentage laagopgeleiden onder de WW-ontvangers. Dit geldt ook voor de MiddenLimburgse gemeente Maasgouw. 


\section{Factsheet \\ ROA-F-2020/5}

\section{FIGUUR 07.}

Relatieve positie van gemeenten op het gebied van gezondheidsproblematiek onder mensen met een WW-uitkering

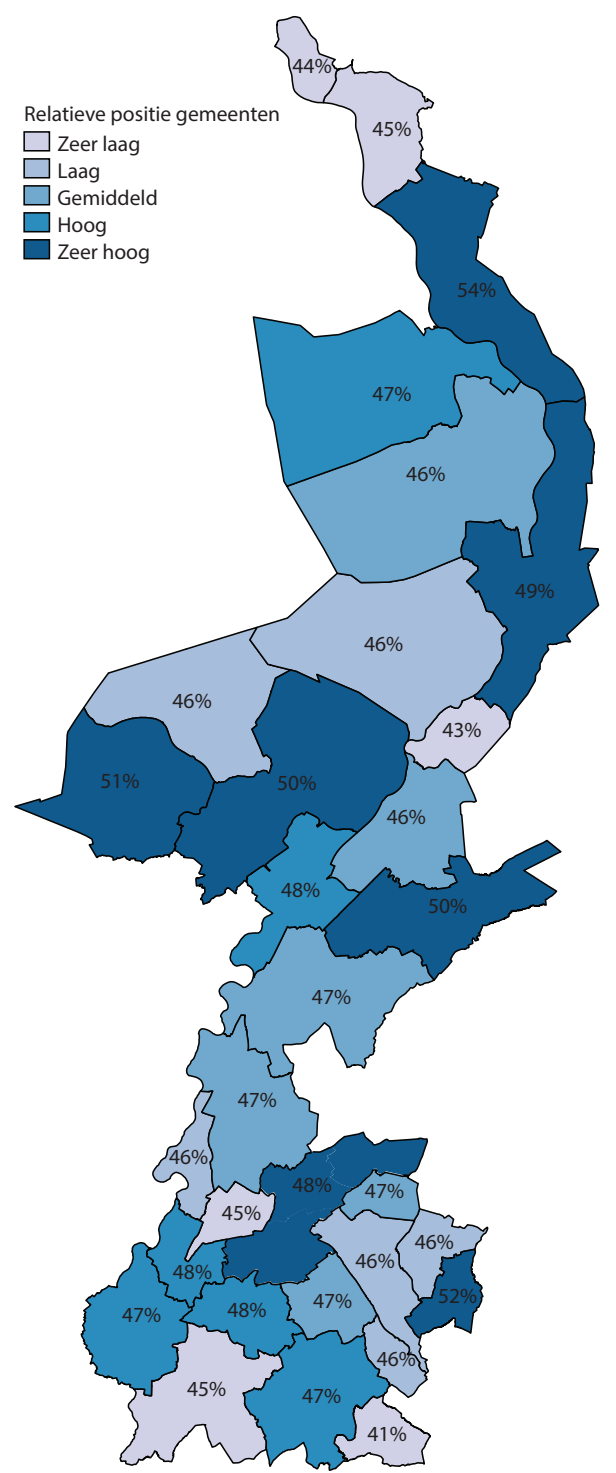

Bron: $R O A$, berekeningen op basis

van microdata van het $C B S$
FIGUUR 08.

Relatieve positie van gemeenten op het gebied van financiële problematiek onder mensen met een WW-uitkering

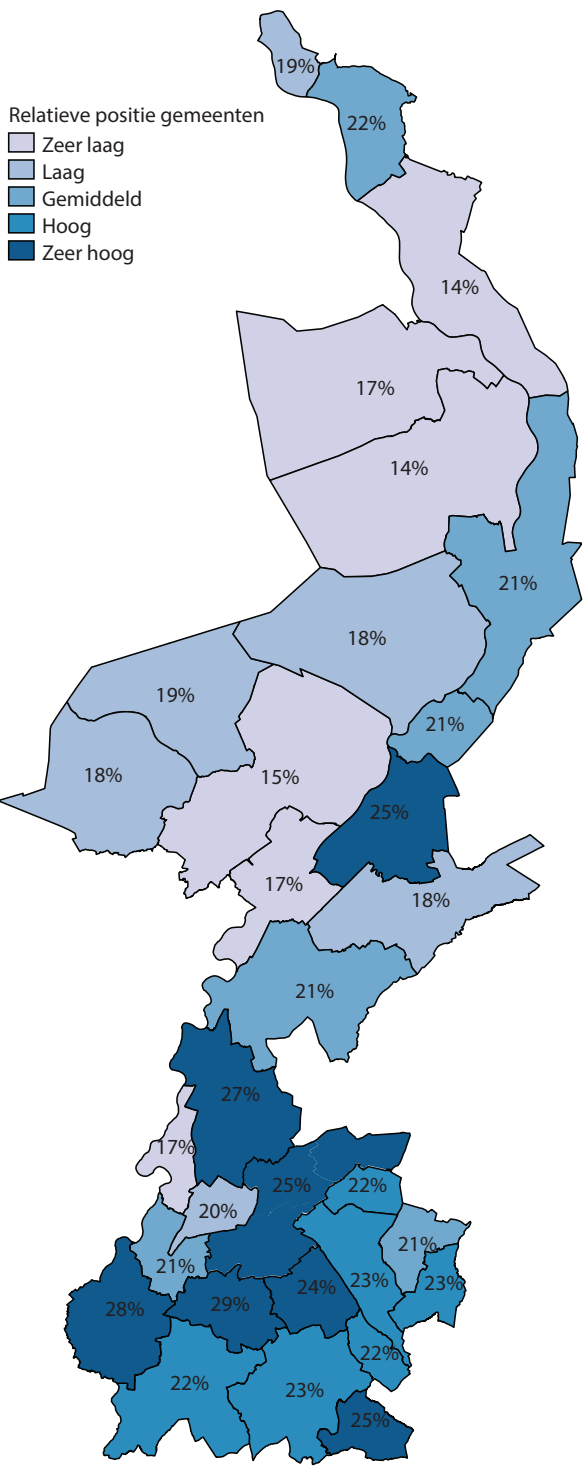

Bron: $R O A$, berekeningen op basis van microdata van het $C B S$
FIGUUR 09.

Relatieve positie van gemeenten op het gebied van laag opleidingsniveau onder mensen met een WW-uitkering

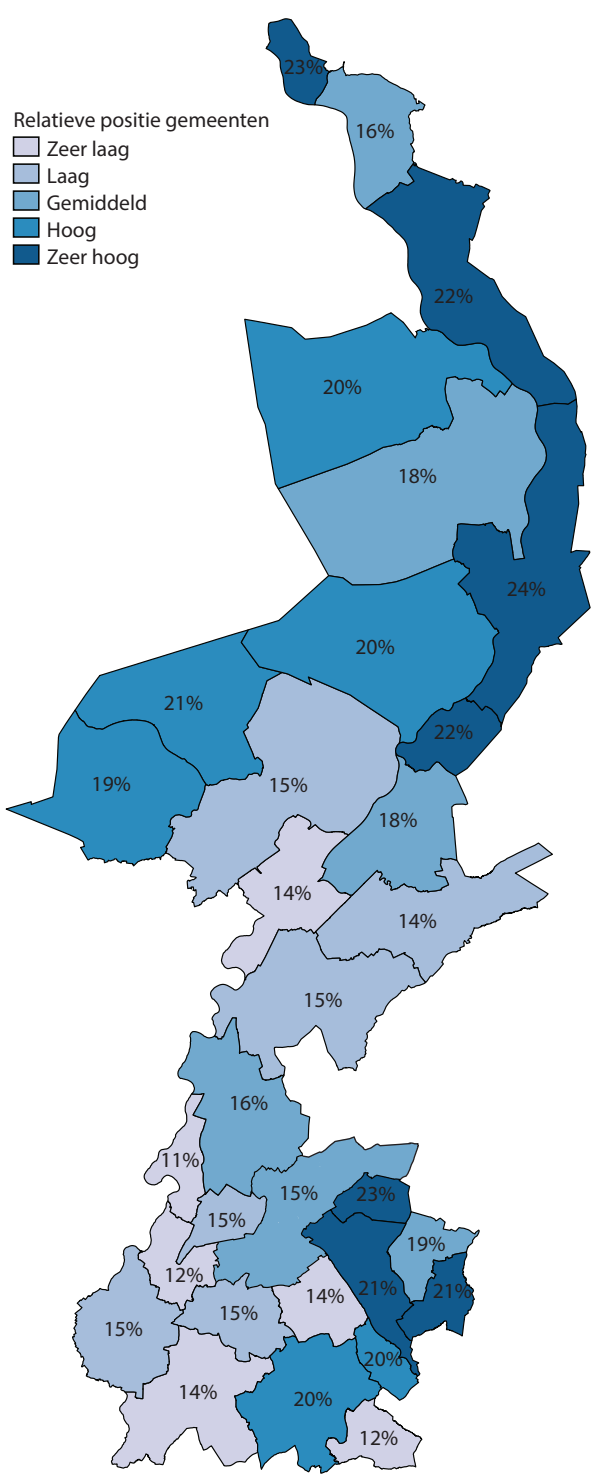

Bron: $R O A$, berekeningen op basis van microdata van het $C B S$ 


\section{Profielschets uitkeringsafhankelijke inwoners in Limburg}

Niet-westerse migratieachtergrond

Uit Figuur 10 blijkt dat een niet-westerse migratieachtergrond onder WW-ontvangers, net als onder AO-ontvangers, in Limburg het meeste voorkomt in de grotere steden: Heerlen, Maastricht, Sittard-Geleen, Weert, Venlo en Roermond. Met name Venray heeft een relatief hoog aandeel niet-westerse migranten onder de WW-ontvangers. In Weert, Venlo en Roermond ligt het percentage mensen met een WW-uitkering dat een nietwesterse migratieachtergrond heeft rond de $8 \%$. In Beek en Leudal ligt dit percentage daarentegen onder de $1 \%$.

\section{Éénoudergezin}

Figuur 11 geeft een overzicht van de mate waarin de WW-ontvangers in de verschillende Limburgse gemeenten deel uitmaken van een éénoudergezin. Uit de figuur blijkt dat éénoudergezinnen onder WW-ontvangers, evenals bij de AO-ontvangers, het meest voorkomen in de Zuid-Limburgse gemeenten. Naast de de steden Maastricht en Heerlen, hebben ook Brunssum, Kerkrade en Beek een relatief zeer hoog percentage éénoudergezinnen onder de WW-ontvangers in hun gemeente. Naast deze ZuidLimburgse gemeenten, behoren ook Roermond en Beesel tot de gemeenten met een relatief zeer hoog percentage éénoudergezinnen onder de WW-ontvangers. In Nederweert maken daarentegen minder dan $1 \%$ van de mensen met een WW-uitkering deel uit van een éénoudergezin. Hiermee behoort Nederweert, evenals de gemeente Eijsden-Margraten, tot de 10 Nederlandse gemeenten met het laagste aandeel éénoudergezinnen onder de WW-ontvangers in hun gemeente.

\section{Complexiteit van de problematiek}

Figuur 12 toont de complexiteitsindex. Uit de figuur blijkt dat in zes Limburgse gemeenten sprake is van een zeer complexe problematiek. Het gaat hier om vijf ZuidLimburgse gemeenten: Brunssum, Heerlen, Kerkrade, Maastricht en Gulpen-Wittem en de Noord-Limburgse gemeente Venlo. Acht Limburgse gemeenten worden gekenmerkt door een enkelvoudige problematiek. Voor Meerssen en Leudal betreft het gezondheidsproblematiek, voor Eijsden-Margraten en Vaals financiële problematiek, voor Mook en Middelaar en Peel en Maas een laag opleidingsniveau, voor Echt-Susteren een nietwesterse migratieachtergrond en voor Beek het het deel uitmaken van een éénoudergezin. Voor een viertal gemeenten geldt dat WW-ontvangers in vergelijking met andere Limburgse gemeenten een zeer sterk profiel hebben. Het betreft hier Landgraaf, Gennep, Stein en Horst aan de Maas. 


\section{Factsheet \\ ROA-F-2020/5}

FIGUUR 10.

Relatieve positie van gemeenten op het gebied van niet-westerse migratieachtergrond onder mensen met een WW-uitkering

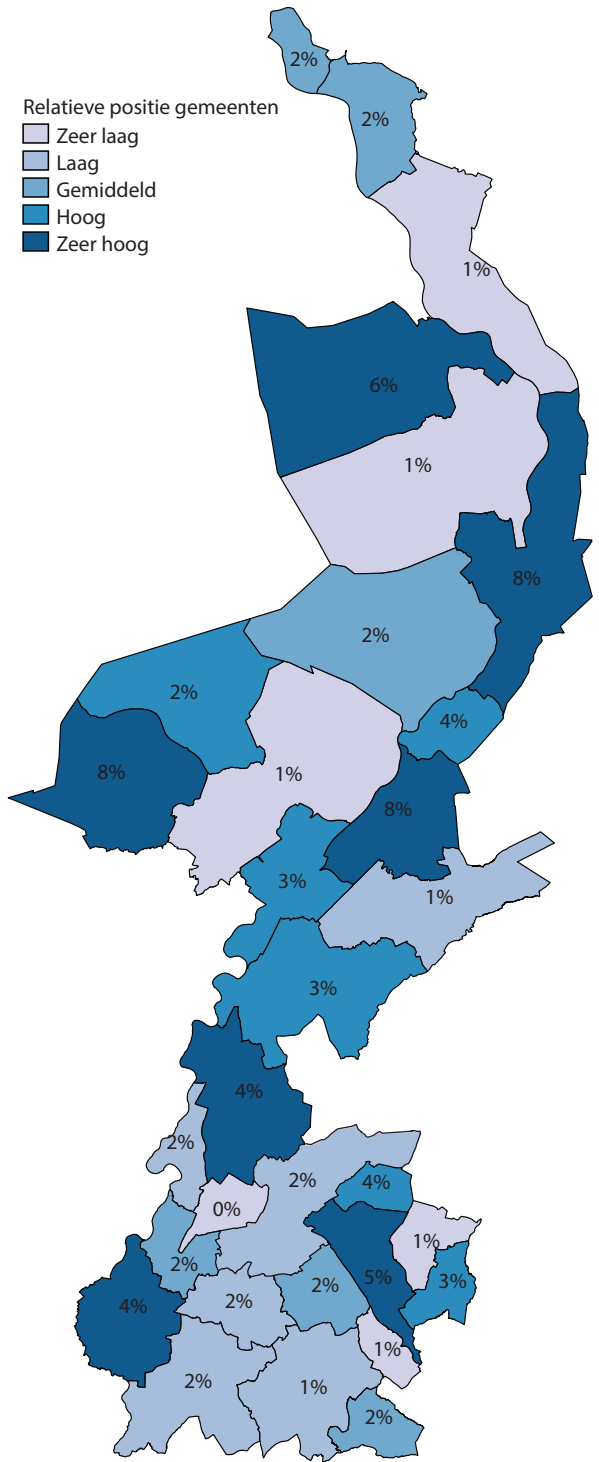

Bron: $R O A$, berekeningen op basis

van microdata van het $C B S$
FIGUUR 11.

Relatieve positie van gemeenten op het gebied van éénoudergezin onder mensen met een WW-uitkering

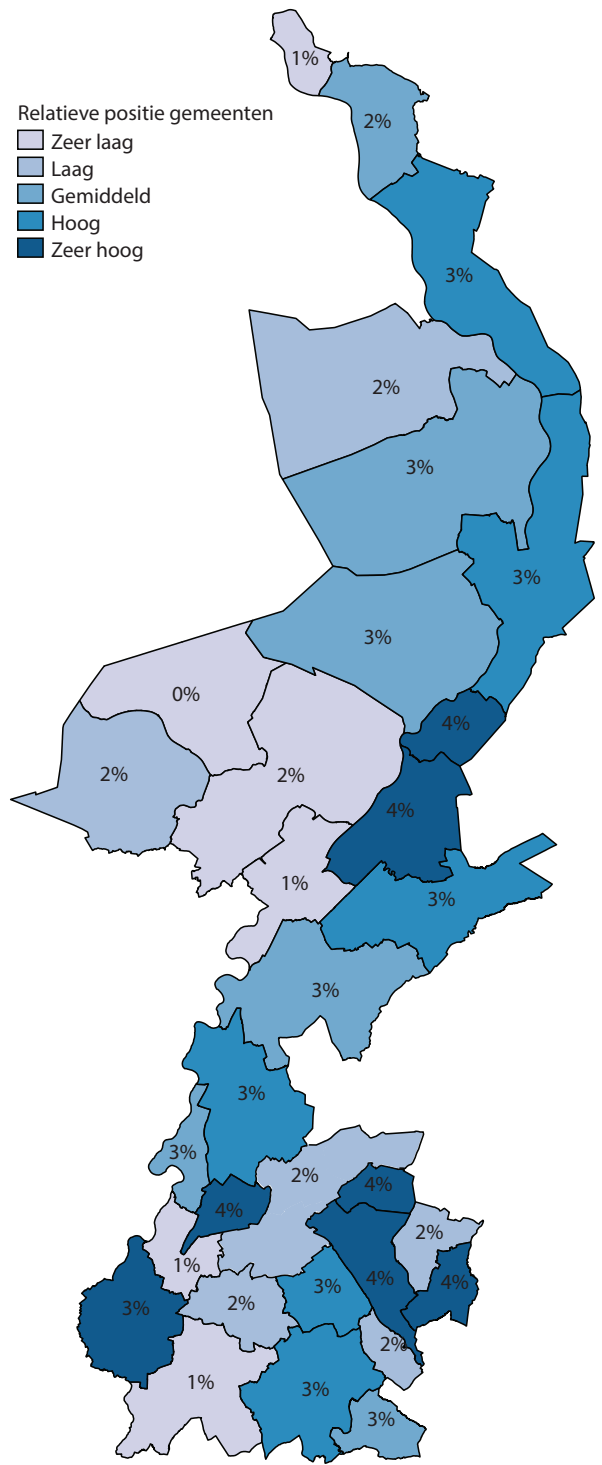

Bron: $R O A$, berekeningen op basis van microdata van het $C B S$
FIGUUR 12.

Complexiteitsindex van gemeenten op gericht op mensen met een WW-uitkering

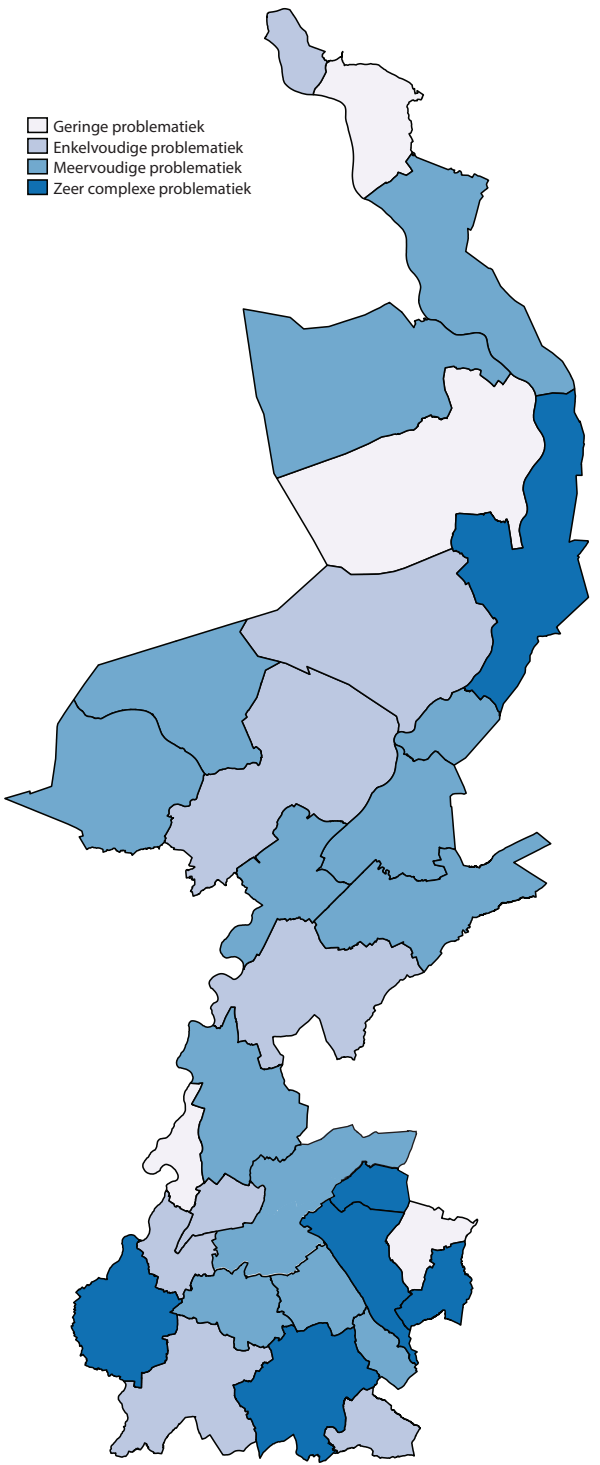

Bron: $R O A$, berekeningen op basis van microdata van het $C B S$ 


\section{Profielschets uitkeringsafhankelijke inwoners in Limburg}

\section{Profielschets van mensen met een bijstandsuitkering in Limburgse gemeenten}

In de Figuren 13-18 is op gemeenteniveau het profiel voor mensen in de bijstand in kaart gebracht. ${ }^{18}$

\section{Gezondheidsproblematiek}

Figuur 13 gaat in op de mate waarop in de Limburgse gemeenten sprake is van gezondheidsproblemen onder de bijstandontvangers. Uit de figuur blijkt dat gezondheidsproblemen onder bijstandontvangers het meest voorkomen in Midden-Limburgse gemeenten. In Roerdalen, Roermond, Weert, EchtSusteren en Nederweert is de gezondheidsproblematiek onder bijstandontvangers het hoogst. Ook in Peel en Maas en Beekdaelen zijn de gezondheidsproblemen onder bijstandontvangers ten opzichte van de andere Limburgse gemeenten zeer hoog.. De zes gemeenten met de minste gezondheidsproblemen onder mensen die een bijstandsuitkering zijn over heel Limburg verspreid. Het betreft hier de gemeenten Valkenburg aan de Geul, Horst aan de Maas, EijsdenMargraten, Gulpen-Wittem, Simpelveld en Gennep. Daarbij moet wel de kanttekening worden gemaakt dat de gezondheidsproblematiek onder bijstandontvangers sowieso erg groot is. Dat betekent dat ook in deze zes gemeenten nog meer dan de helft van de mensen in de bijstand gezondheidsproblemen ervaren. Gezondheidsproblemen blijken zich dus beduidend meer voor te doen bij mensen met bijstandsuitkering dan bij mensen met een WW-uitkering.

\section{Financiële problematiek}

In Figuur 14 is in kaart gebracht in hoeverre mensen in de bijstand te kampen hebben met financiële problemen. In alle Limburgse gemeenten heeft tussen de $62 \%$ en $79 \%$ van alle bijstandontvangers financiële problemen. Het betreft hier schulden van minimaal 10.000 Euro, deelname in een schuldsaneringstraject of een huishoudinkomen onder de armoedegrens. In zeven gemeenten komen financiële problemen relatief gezien zeer veel voor onder bijstandsontvangers (tussen de $75 \%$ en $79 \%$ ). Het gaat hier om de gemeenten Beekdaelen, Sittard-Geleen, Maastricht, Heerlen, Vaals, Kerkrade en Valkenburg aan de Geul. Dit zijn allemaal Zuid-Limburgse gemeenten. Ook in de Zuid-Limburgse gemeenten Landgraaf, Brunssum, Gulpen-Wittem en Beek komen financiële problemen onder bijstandsontvangers relatief veel voor. In het merendeel van de Noord- en Midden-Limburgse gemeenten komen financiële problemen bij minder dan $70 \%$ van de bijstandontvangers voor. Uitzonderingen zijn: Echt-Susteren (71\%), Venray (72\%), Venlo (73\%), Roermond (73\%) en Weert (74\%).

\section{Laag opleidingsniveau}

Figuur 15 laat zien in welke mate mensen in de bijstand in Limburgse gemeenten een laag opleidingsniveau hebben. De percentages lopen uiteen van $36 \%$ tot $64 \%$. Er is geen duidelijke geografische concentratie. In de gemeenten Peel en Maas, Eijsden-Margraten, Mook en Middelaar,oerendaal, Simpelveld en Gennep zijn relatief zeer weinig bijstandsontvangerslaag opgeleid. Dit in tegenstelling tot de gemeenten Landgraaf, Roerdalen, Kerkrade, Beek, Sittard-Geleen, Venlo en Nederweert waar minimaal $60 \%$ van de bijstandsontvangers een laag opleidingsniveau heeft. 


\section{Factsheet \\ ROA-F-2020/5}

\section{FIGUUR 13.}

Relatieve positie van gemeenten op het gebied van gezondheidsproblematiek onder mensen in de bijstand

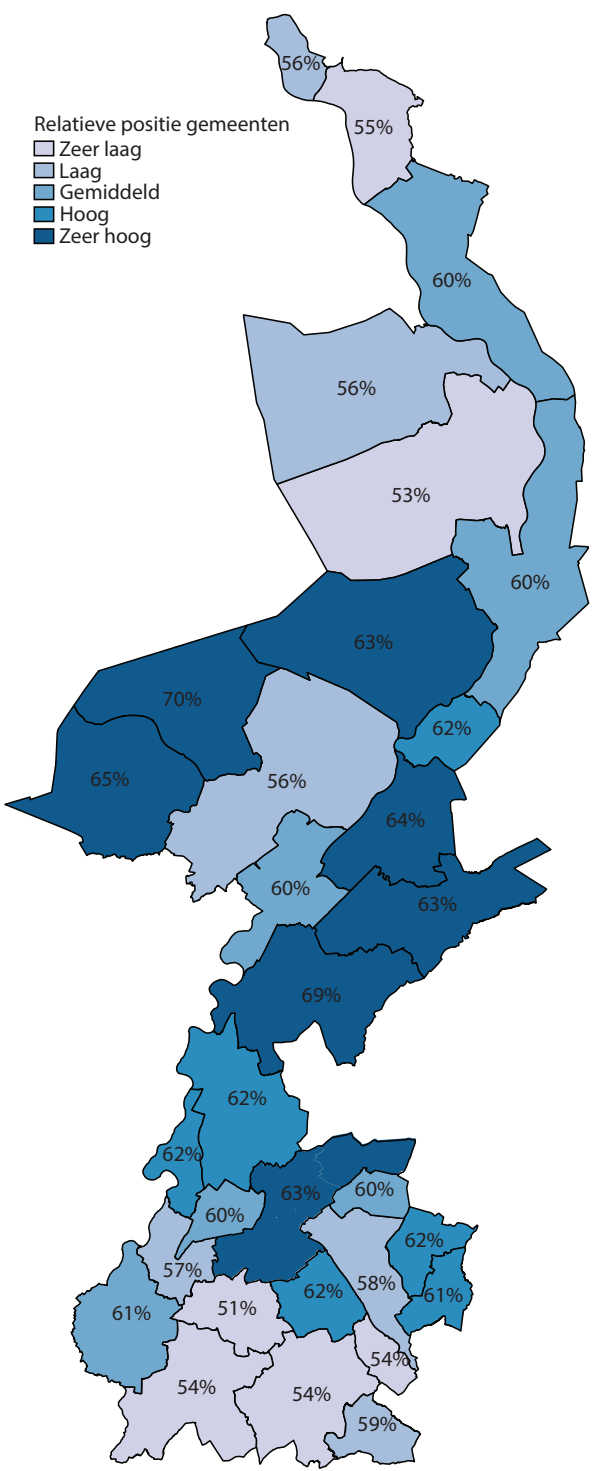

Bron: $R O A$, berekeningen op basis

van microdata van het $C B S$

\section{FIGUUR 14.}

Relatieve positie van gemeenten op het gebied van financiële problematiek onder mensen in de bijstand

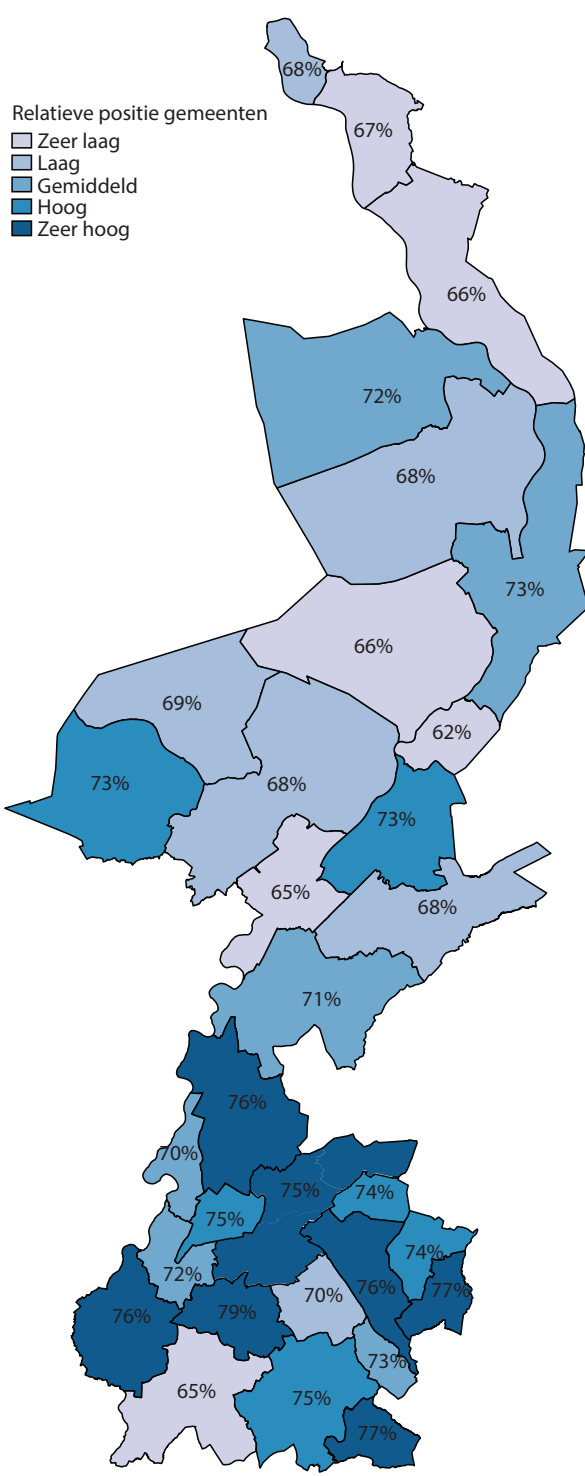

Bron: $R O A$, berekeningen op basis van microdata van het $C B S$
FIGUUR 15.

Relatieve positie van gemeenten op het gebied van laag opleidingsniveau onder mensen in de bijstand

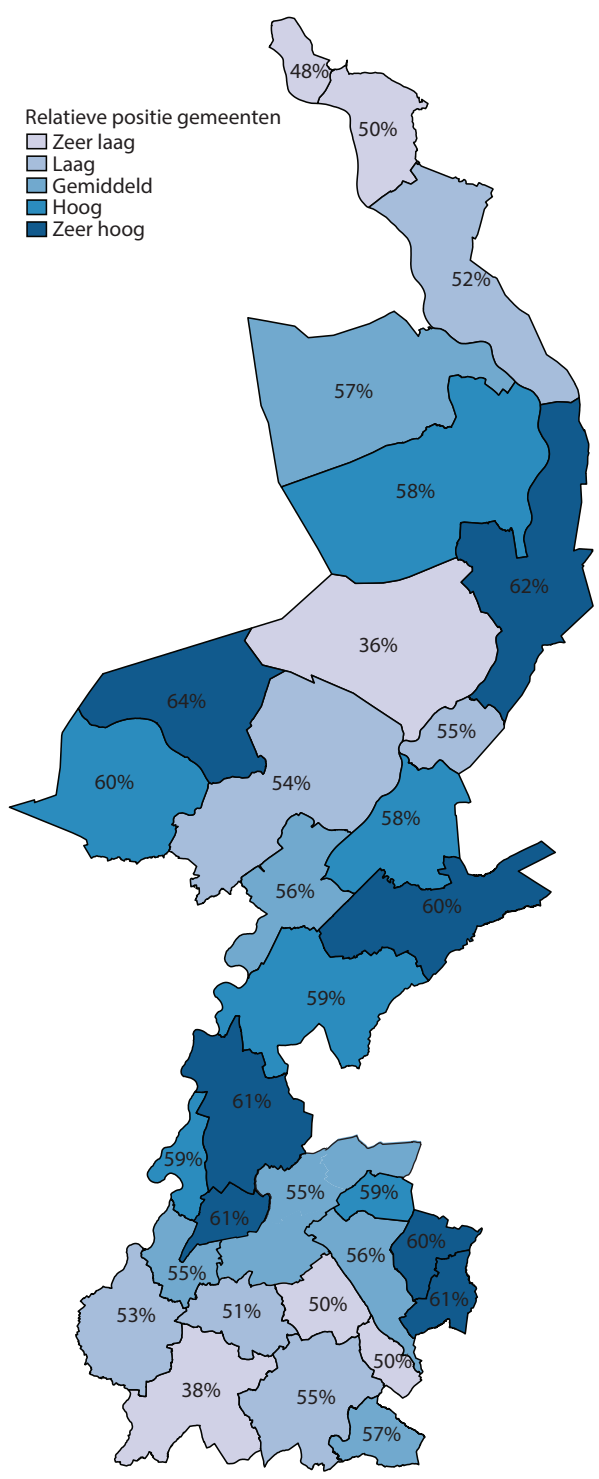

Bron: $R O A$, berekeningen op basis van microdata van het $C B S$ 


\section{Profielschets uitkeringsafhankelijke inwoners in Limburg}

Niet-westerse migratieachtergrond

In Figuur 16 is de regionale spreiding van bijstandsontvangers met een niet-westerse migratieachtergrond in kaart gebracht. Onder mensen in de bijstand komt het hebben van een niet-westerse migratieachterond het meeste voor in Noord en Midden-Limburg. In de gemeenten Venlo, Weert, Beek, Horst aan de Maas, Roermond, Venray en Mook en Middelaar is er sprake van een relatief zeer hoog aandeel niet-westerse migranten onder de bijstandsontvangers (tussen de 29 en 33\%). In Landgraaf, Valkenburg aan de Geul, Brunssum, Bergen, Simpelveld en Leudal geldt juist dat er relatief gezien zeer weinig mensen in de bijstand een niet-westerse migratieachtergrond hebben (minder dan 20\%). Over het algemeen genomen komt een niet-westere migratieachtergrond onder mensen in de bijstand (zeer) weinig voor in de Zuid-Limburgse gemeenten.

\section{Éénoudergezin}

In Figuur 17 is het percentage en de relatieve positie van gemeenten m.b.t. het voorkomen van éénoudergezinnen onder mensen in de bijstand weergegeven. Uit de figuur blijkt dat éénoudergezinnen onder bijstandsontvangers het meest voorkomen (tussen de 15-17\%) in de Oostelijke mijnstreek, - Voerendaal, Landgraaf, Heerlen en Brunssum - alsook in Venlo, Beesel en Venray. In Gulpen-Wittem, Meerssen, Eijsden-Margraten, Maasgouw, Stein en Leudal komt het juist relatief gezien zeer weinig voor dat bijstandsontvangers deel uitmaken van een éénoudergezin (maximaal 10,3\%).

\section{Complexiteit van de problematiek}

In Figuur 18 wordt de complexiteitsindex getoond voor bijstandsontvangers. De index is een optelsom van het aantal reïntegratie belemmerende factoren, dat in een gemeente relatief zeer vaak voorkomt. Uit de figuur blijkt dat vier gemeenten sprake is van een zeer complexe problematiek. In deze gemeenten komen vier of vijf van de onderscheiden factoren relatief vaak voor onder de bijstandsontvangers. Het gaat hier om de gemeenten Landgraaf, Kerkrade, Roermond en Weert. Bij 18 van de 31 Limburgse gemeenten is er sprake van een meervoudige problematiek: bij deze gemeenten is de problematiek onder de bijstandontvangers op twee of drie aspecten (zeer) hoog. In een zestal gemeenten is de problematiek enkelvoudig, wat betekent dat in deze gemeenten slechts één aspect (zeer) vaak voorkomt onder de bijstandsontvangers. Het gaat hier om de gemeenten Bergen en Simpelveld (éénoudergezin), Meerssen en Maasgouw (niet-westerse migratieachtergrond), Valkenburg aan de Geul en Gulpen-Wittem (financiële problematiek). In Gennep, Leudal en Eijsden-Margraten hebben de bijstandsontvangers in vergelijking met de andere Limburgse gemeenten weinig te maken met de vijf aspecten die de reïntegratie bemoeilijken. 


\section{Factsheet}

ROA-F-2020/5

FIGUUR 16.

Relatieve positie van gemeenten op het gebied van niet-westerse migratieachtergrond onder mensen in de bijstand

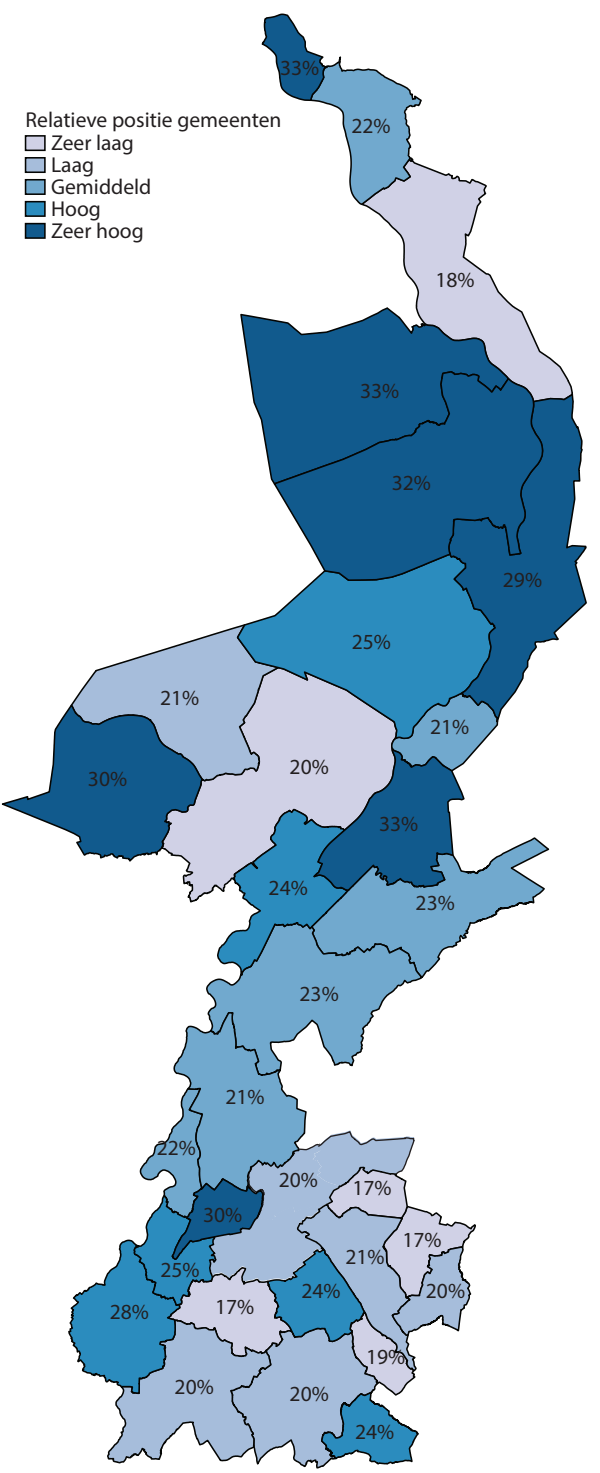

Bron: $R O A$, berekeningen op basis

van microdata van het $C B S$

\section{FIGUUR 17.}

Relatieve positie van gemeenten op het gebied van éénoudergezin onder mensen in de bijstand

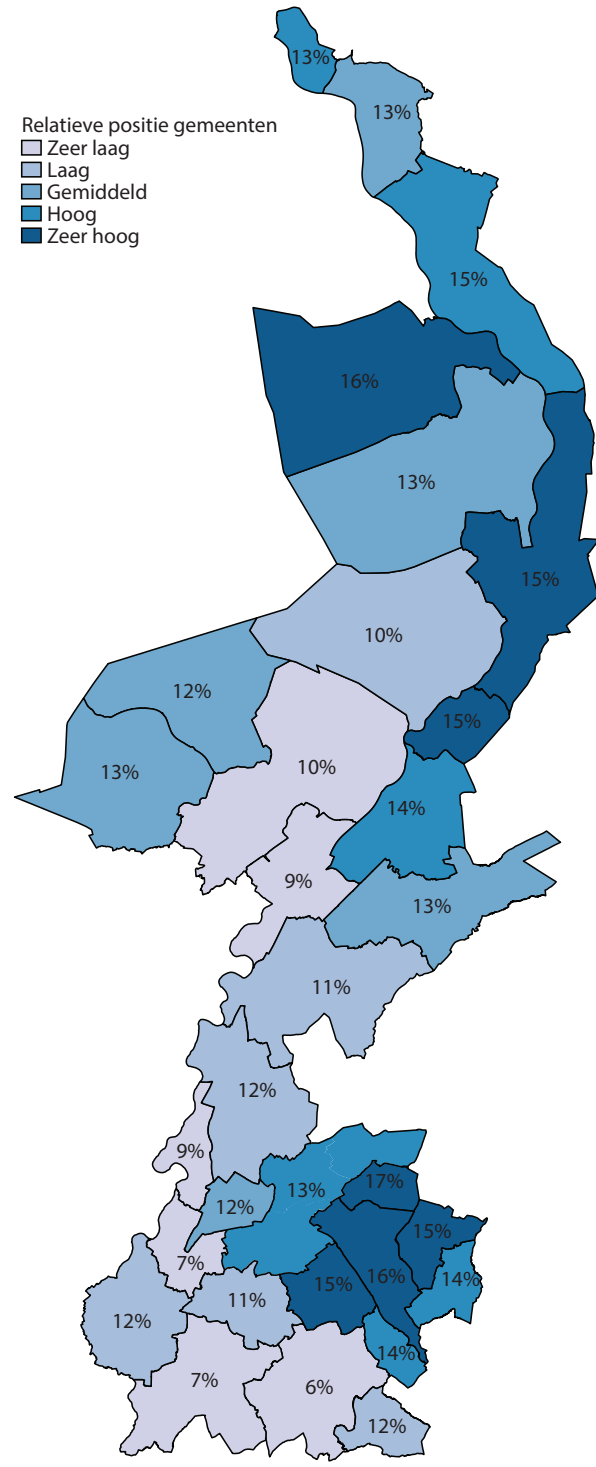

Bron: $R O A$, berekeningen op basis

van microdata van het $C B S$
FIGUUR 18.

Complexiteitsindex van gemeenten gericht op mensen in de bijstand

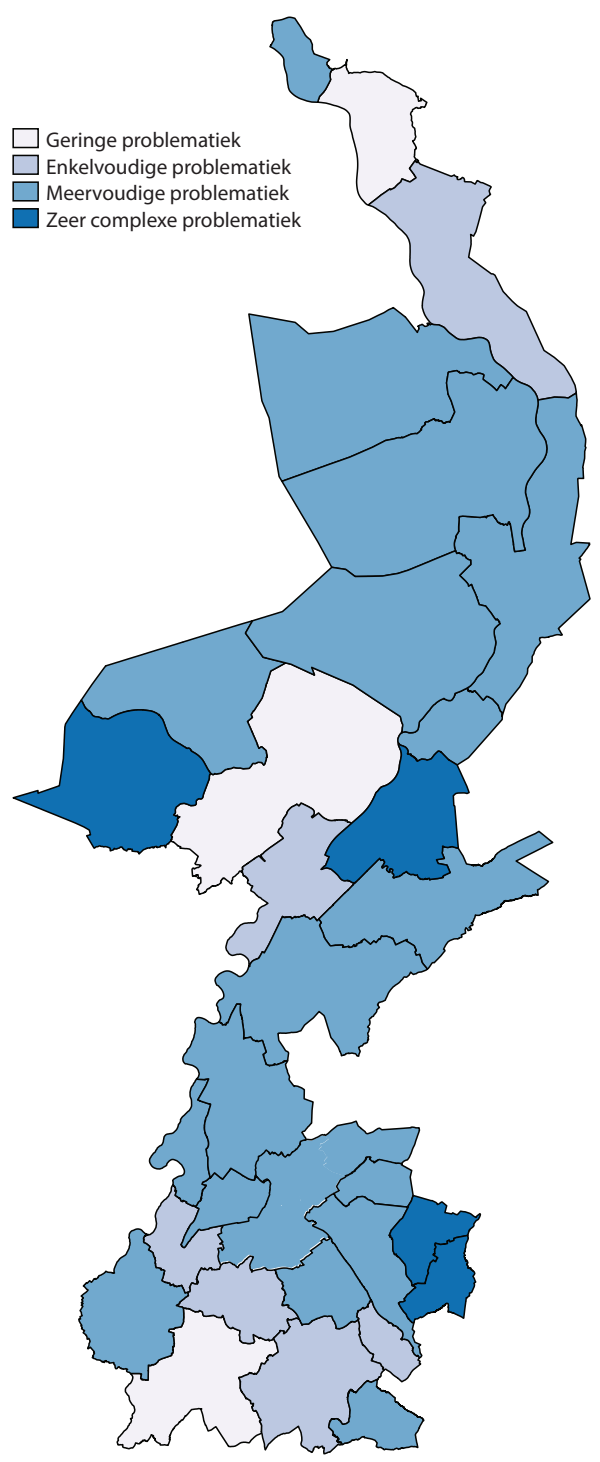

Bron: $R O A$, berekeningen op basis van microdata van het $C B S$ 


\section{Profielschets uitkeringsafhankelijke inwoners in Limburg}

\section{Endnotes}

1 De potentiële beroepsbevolking wordt door ons gedefinieerd als alle inwoners in de leeftijd van 15 tot en met 67 jaar.

2 Künn \& Poulissen (2018). Omvang kwetsbare groepen in Limburg, ROA-F-2018/20. De informatie in deze factsheet beschreef de situatie in december 2015 en kon daarmee gezien worden als nulmeting voor de Sociale Agenda Limburg.

3 Mensen die de AOW-gerechtigde leeftijd hebben bereikt en mensen die een pensioenuitkering ontvangen worden niet als inactief bestempeld. Hetzelfde geldt voor degenen die initieel onderwijs volgen.

4 Daarbij kijken we naar de inwoners die in december 2017 een uitkering ontvingen, en niet schoolgaand waren of daarnaast een (vervroegd) pensioen ontvingen. Bij de profielschetsen naar gemeente blijven de inactieven zonder uitkering buiten beschouwing, omdat hun profiel over de gehele linie veel sterker is dan dat van uitkeringsafhankelijken.

5 Zie voor de operationalisatie van deze dimensies: Künn-Nelen, A., Poulissen, D., De Grip, A. (2020). Operationalisatie profielschetsen kwetsbare groepen, ROA-TR-2020/6.

6 Informatie over het opleidingsniveau is alleen gebaseerd op inwoners geboren na 1994. Deze toevoeging wordt in de rest van de factsheet niet voortdurend herhaald.

7 Het al dan niet hebben van een niet-Westerse migratieachtergond is gebaseerd op het geboorteland van de persoon zelf en dat van zijn of haar ouders.

8 Zie: Künn-Nelen, A., Poulissen, D., De Grip, A. (2020). Profielschets bijstandsontvangers Heerlen - de complexiteit van de problematiek en reïntegratiekansen, ROA-R2020/3. In deze rapportage richten we ons op mensen in de bijstand. De mogelijkheden voor het maken van profielschetsen op wijkniveau hangen af van de omvang van de kwetsbare groepen per wijk.

9 Zie bijvoorbeeld:

Gornick, J. (2018). The socioeconomics of single parenthood: Reflections on the triple bind. In Nieuwenhuis R. \& Maldonado L. (Eds.), The triple bind of single-parent families: Resources, employment and policies to improve wellbeing (pp. 437-448). Bristol, UK;
Corsini, L. (2012). Unemployment insurance schemes, liquidity constraints and re-employment: A three country comparison. Comparative Economic Studies, 54(2), 321-340; Constant, A. F., Kahanec, M., Rinne, U., \& Zimmermann, K. F. (2011). Ethnicity, job search and labor market reintegration of the unemployed. International Journal of Manpower, 32(7), 753-776;

Riddell, W. C., \& Song, X. (2011). The impact of education on unemployment incidence and re-employment success: Evidence from the US labour market. Labour Economics, 18(4), 453-463;

García-Gómez, P., Jones, A. M., \& Rice, N. (2010). Health effects on labour market exits and entries. Labour Economics, 17(1), 62-76.

10 Zie voor de constructie van deze index: Künn-Nelen, A., Poulissen, D., De Grip, A. (2020). Operationalisatie profielschetsen kwetsbare groepen, ROA-TR-2020/6.

11 Zie ook: Erdem, Ö., van de Kamp, D., Schouten, G., \& Hajema, K. (2018). Gemeentelijke verschillen in ervaren gezondheid. Statistische Trends, CBS.

$12 \mathrm{Er}$ is voor het maken van de kaarten gebruik gemaakt van Kadaster/CBS, Wijk- en buurtkaart 2020.

13 In bijlage $A$ is de ranking van gemeenten ten opzichte van alle Nederlandse gemeenten weergegeven m.b.t. het voorkomen van de vijf aspecten onder arbeidsongeschikten.

14 Zoals te zien in Tabel A1 in de appendix, neemt Simpelveld op dit punt onder alle Nederlandse gemeenten de 9 e plaats in.

15 Omdat de index gebaseerd is op de relatieve positie van gemeenten, is er in feite sprake van een relatief zeer complexe problematiek.

16 In bijlage $B$ is de ranking van gemeenten ten opzichte van alle Nederlandse gemeenten weergegeven m.b.t. het voorkomen van de vijf aspecten onder mensen met een werkloosheidsuitkering.

17 Onder zowel de AO-ontvangers als de WW-ontvangers geldt dat ongeveer $24 \%$ laag opgeleid is.

18 In bijlage $\mathrm{C}$ is de ranking van gemeenten ten opzichte van alle Nederlandse gemeenten weergegeven met betrekking tot het voorkomen van de vijf aspecten onder mensen in de bijstand. 


\section{Factsheet}
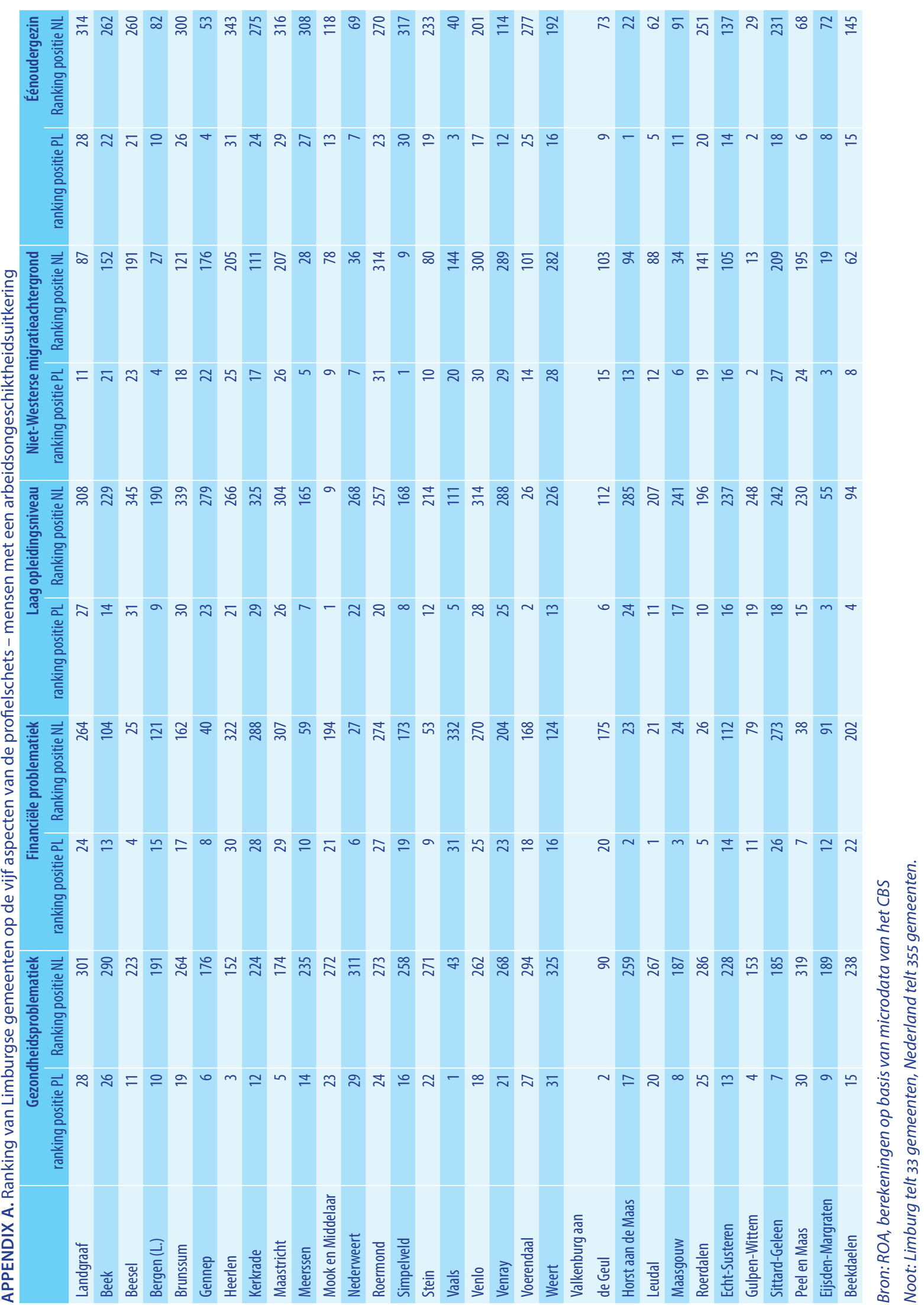


\section{Profielschets uitkeringsafhankelijke inwoners in Limburg}

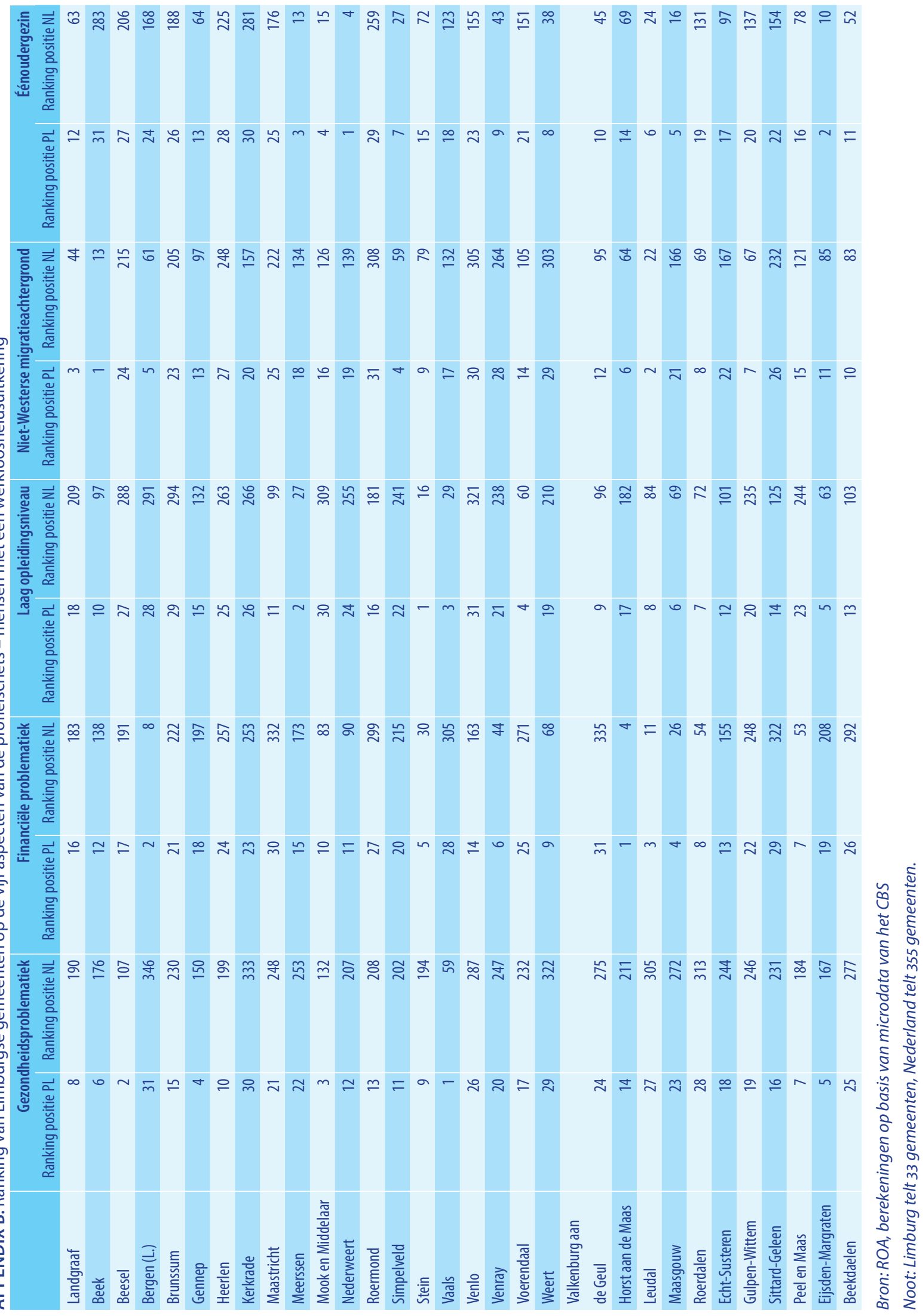




\section{Factsheet}
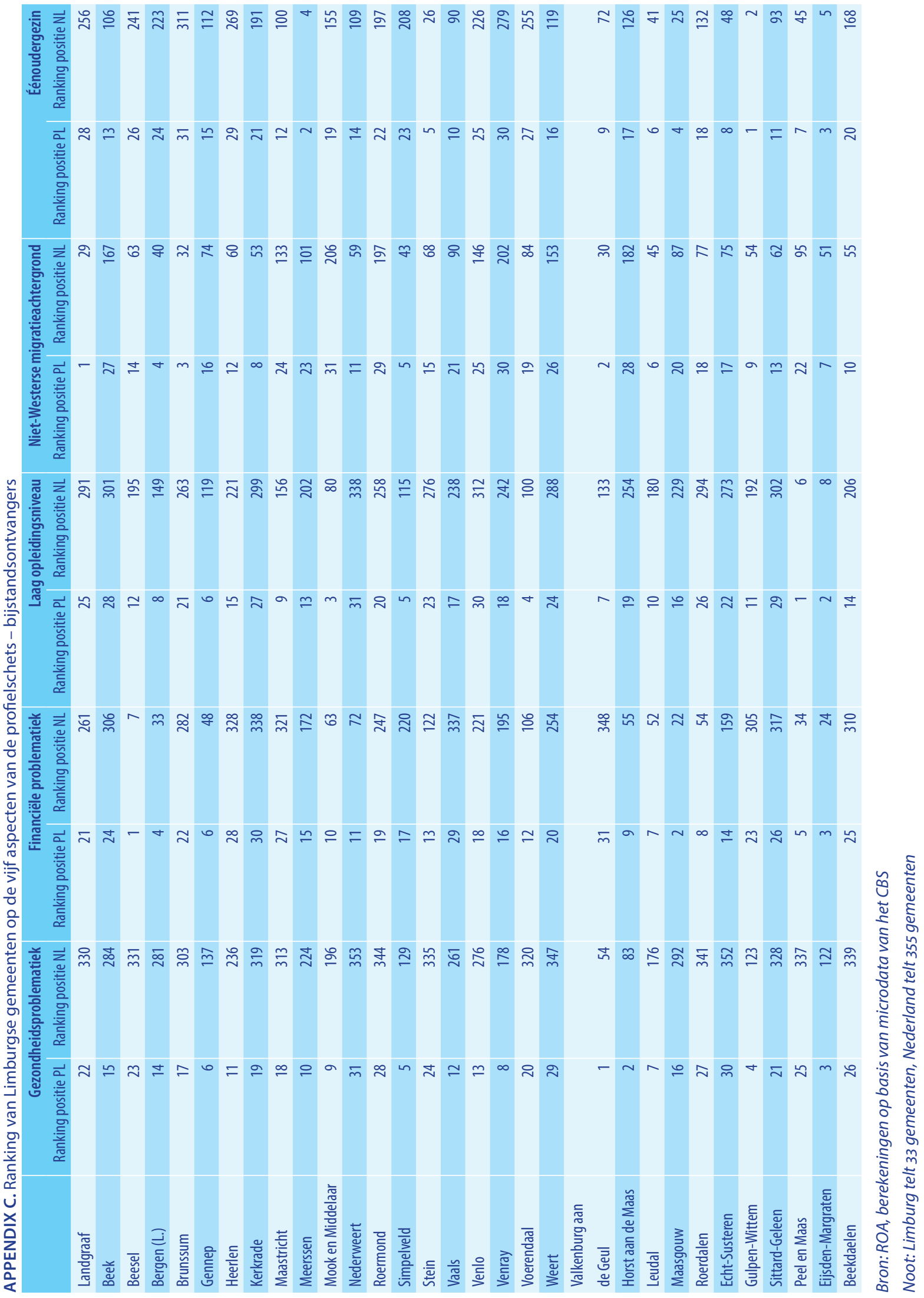


\section{\$ 4 LIMBURG}

Deze factsheet is een onderdeel van het meerjarenprogramma 4Limburg dat een bijdrage wil leveren om de Limburgse samenleving meer duurzaam, vitaal en inclusief te maken. Het doel van dit programma is om, in nauwe samenwerking met de Universiteit Maastricht, Provincie Limburg en ketenpartners zoals gemeenten, UWV en bedrijfsleven, via een trendbreuk de arbeidsparticipatie én de vitaliteit in Limburg naar een hoger niveau te tillen. Er zijn in Limburg veel mensen zonder werk onder de potentiële beroepsbevolking. Inzicht in de (complexiteit van de) problematiek van kwetsbare inwoners is nodig alvorens initiatieven kunnen zorgen voor een inclusieve arbeidsmarkt waar iedereen in kan participeren. Deze factsheet brengt op basis van een profielschets in kaart wat de (complexe) problematiek is van uitkeringsafhankelijken woonachtig in de verschillende gemeenten in Limburg.

\section{Colofon}

(๔) Researchcentrum voor Onderwijs en Arbeidsmarkt Niets uit deze uitgave mag op enige manier worden verveelvoudigd zonder voorafgaande schriftelijke toestemming van de directeur van het ROA.

\section{Researchcentrum voor Onderwijs en Arbeidsmarkt}

Maastricht University

School of Business and Economics

secretary-roa-sbe@maastrichtuniversity.nl

www.roa.nl

\section{Vormgeving}

ROA secretariaat, Maastricht

juli 2020 